\title{
Impact of the Prevalence of Concordant and Discordant Conditions on the Quality of Diabetes Care in Family Practices in England
}

Ignacio Ricci-Cabello, $\mathrm{PbD}^{1}$

Sarab Stevens, MSc ${ }^{1}$

Evangelos Kontopantelis, $\mathrm{PbD}^{2,3}$

Andrew R. H. Dalton, $P b D^{1}$

Robert I. Griffiths, $S_{c} D^{1}$

Jobn L. Campbell, $M D^{5}$

Tim Doran, $P b D^{4}$

Jose M. Valderas, $\mathrm{PbD}^{1,5}$

'Nuffield Department of Primary Care Health Sciences, University of Oxford, Oxford, United Kingdom

${ }^{2}$ National Institute for Health Research (NIHR) School for Primary Care Research, Centre for Primary Care, Institute of Population Health, University of Manchester, Manchester, United Kingdom

${ }^{3}$ Centre for Health Informatics, Institute of Population Health, University of Manchester, Manchester, United Kingdom

${ }^{4}$ Department of Health Sciences, University of York, York, United Kingdom

${ }^{5}$ APEx Collaboration for Academic Primary Care, Institute for Health Services Research, University of Exeter Medical School, University of Exeter, Exeter, United Kingdom

Conflicts of interest: authors report none.

\section{CORRESPONDING AUTHOR}

Ignacio Ricci-Cabello, $\mathrm{PhD}$

Nuffield Department of Primary Care

Health Sciences

University of Oxford

Gibson Building, 1st Floor, Radcliffe

Observatory Quarter

Woodstock Road

Oxford OX2 6GG, England

ignacio.riccicabello@phc.ox.ac.uk

\begin{abstract}
PURPOSE The purpose of this study was to examine the association between the prevalence of both diabetes-concordant and diabetes-discordant conditions and the quality of diabetes care at the family practice level in England. We hypothesized that the prevalence of concordant (or discordant) conditions would be associated with better (or worse) quality of diabetes care.
\end{abstract}

METHODS We conducted a cross-sectional study using practice-level data $(7,884$ practices). We estimated the practice-level prevalence of diabetes and 15 other chronic conditions, which were classified as diabetes concordant (ie, with the same pathophysiologic risk profile and therefore more likely to be part of the same management plan) or diabetes discordant (ie, not directly related in either their pathogenesis or management). We measured quality of diabetes care with diabetes-specific indicators (8 processes and 3 intermediate outcomes of care). We used linear regression models to quantify the effect of the prevalence of the conditions on aggregate achievement rate for quality of diabetes care.

RESULTS Consistent with the proposed model, the prevalence rates of 4 of 7 concordant conditions (obesity, chronic kidney disease, atrial fibrillation, heart failure) were positively associated with quality of diabetes care. Similarly, negative associations were observed as predicted for 2 of the 8 discordant conditions (epilepsy, mental health). Observations for other concordant and discordant conditions did not match predictions in the hypothesized model.

CONCLUSIONS The quality of diabetes care provided in English family practices is associated with the prevalence of other major chronic conditions at the practice level. The nature and direction of the observed associations cannot be fully explained by the concordant-discordant model.

Ann Fam Med 2015;13:514-522. doi: 10.1370/afm.1848.

\section{INTRODUCTION}

Dype 2 diabetes is a common, lifelong condition affecting 3.1 million people in England. ${ }^{1}$ Accordingly, providing high-quality diabetes

1 care is an important priority for the English National Health Service, and family (general) practices are mainly responsible for delivering most of this care. ${ }^{2}$

Quality of diabetes care in family practices has been examined primarily in relation to the individual patients. ${ }^{3}$ Less evidence exists regarding the practice-level factors that could influence diabetes care. Available evidence suggests that some characteristics of family practices and the populations they serve, including deprivation (more affluent practice population), list size (larger), and geography (urban), are associated with higher quality of diabetes care. ${ }^{3 \cdot 7}$ The volume of patients with diabetes per practice has also been examined as a potential determinant of quality of diabetes care, but the evidence is inconclusive. ${ }^{5,8,9}$

No study, however, has previously assessed the potential impact of the practice-level prevalence of diabetes-concordant and -discordant condi- 
tions on quality of diabetes care. It is possible that family practices with a higher proportion of patients having different diseases in the cardiometabolic cluster (ie, diabetes and diabetes-concordant conditions) prioritized and more efficiently allocated resources for the management of these conditions, ${ }^{10}$ potentially improving the quality of health care for patients with diabetes. Conversely, those practices with a higher proportion of patients who have diabetes-discordant conditions (ie, those that are not directly related to each other in either their pathogenesis or management) could be impaired in their ability to deliver high-quality diabetes care as a result of competition for resources and attention.

The notion of concordant and discordant conditions, initially proposed to characterize comorbidities in relation to an index disease at the patient level, ${ }_{1}^{11}$ could also have implications for health services evaluation and improvement at the practice level. In England, capitation payments are distributed to practices according to their list size, population age, social deprivation, or practice location, but not to their disease prevalence profile. ${ }^{12}$

We conducted a study to explore whether the practice-level prevalence of diabetes-concordant and -discordant conditions could explain variations in the quality of health care provided to patients with diabetes registered in family practices in England.

\section{METHODS}

\section{Study Design and Setting}

We conducted a cross-sectional study using data from family practices in England, where the great majority of the population is registered with a family practice for the provision of primary care services, which are free at the point of care. Computerization is almost complete and driven by participation in the profitable Quality and Outcomes Framework (QOF) ${ }_{1}^{13}$ a national pay-for-performance scheme. ${ }^{14}$

We included data for all family practices participating in the scheme, which provides care for more than 99\% of patients registered in England. We excluded practices that had incomplete data, provided only specialized services (eg, addiction services), served primarily specialized populations (eg, care homes), and had no recorded patients with diabetes. The analyses are based on 7,884 practices (96\% of all practices).

\section{Data Sources}

Data on indicators for quality of diabetes care and on exception reporting rates (proportion of patients registered in the practice who had been excluded from QOF calculations) for the financial year 2012-2013 were obtained from the Quality Management and Analysis System (QMAS), which automatically extracts data from the clinical record systems of practices. We obtained demographic data, number of general practitioners per practice, and the Carr-Hill normalized practice weighted list size ${ }^{15}$ (used for resource allocation for family practices in England, as it includes a number of adjustments to ensure that resources reflect more accurately the contractor's workload and the unavoidable costs of delivering high-quality care to the local population) from the Health and Social Care Information Center Indicator Portal. ${ }^{16}$ We also obtained the Index of Multiple Deprivation (IMD) ${ }^{17}$ for the practice postcodes from the Department of Communities and Local Government. ${ }^{18}$ The IMD is calculated at the level of Lower Layer Super Output Area (geographical areas containing about 1,500 residents), which is based on 38 indicators organized across 7 different domains of deprivation (income, employment, health and disability, education, housing and services, living environment, and crime).

The data for this study are publicly available. In keeping with the requirements of Oxford University, the authors did not seek human subjects approval.

\section{Prevalence of Concordant and Discordant Conditions}

For each practice we calculated the prevalence for diabetes and each of 15 chronic conditions based on the number of patients with the index condition on the clinical register of each practice (numerator) as a percentage of the total number of patients on practices' lists (denominator).

We established a map of shared pathophysiologic associations ${ }^{11,19-21}$ (Figure 1) and used it to classify conditions as either diabetes-concordant (obesity, hypertension, coronary heart disease, chronic kidney disease, stroke/transient ischemic attack, atrial fibrillation, and heart failure) or diabetes-discordant (asthma, cancer, chronic obstructive pulmonary disease [COPD], dementia, depression, epilepsy, hypothyroidism, and severe mental health disorders, such as schizophrenia, bipolar disorder, and other psychoses).

\section{Quality of Diabetes Care}

We used 2 overall measures of practice-level quality of diabetes care: (1) process of care, and (2) intermediate outcomes. They were based on 8 (processes) and 3 (intermediate outcomes) evidence-based, diabetesspecific indicators in the QOF for 2012 to 2013 (Table 1). ${ }^{22-24}$ We used logit transformation of the reported achievement rate in each practice for each indicator (proportion of eligible patients for which the target was met) because of the highly skewed distribution 


\section{Figure 1. Etiopathophysiologic relation between concordant conditions.}

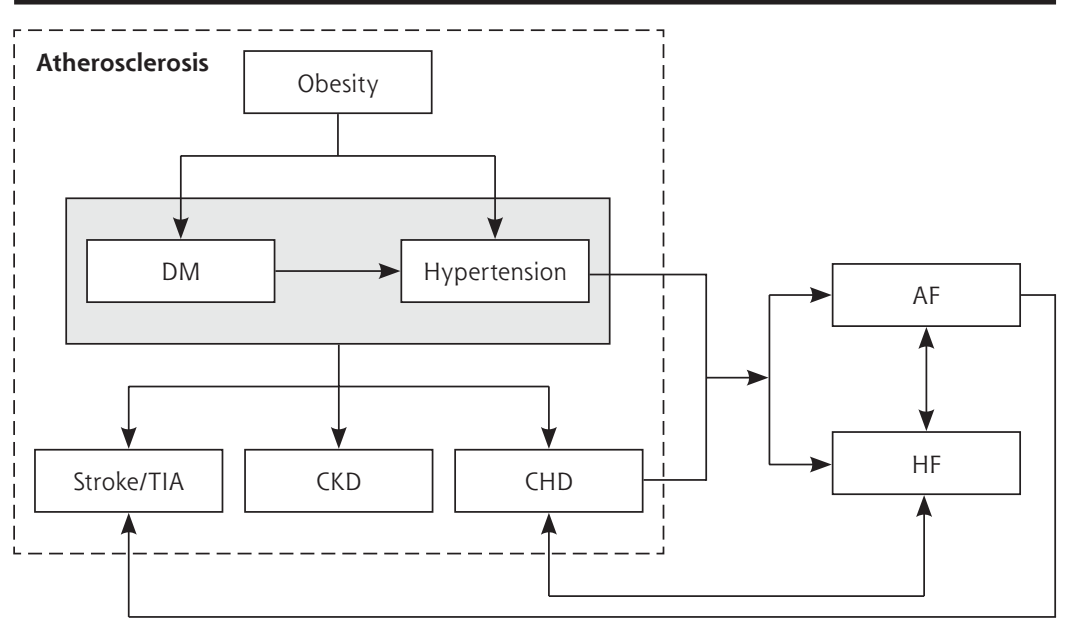

$\mathrm{AF}=$ atrial fibrillation; $\mathrm{CHD}=$ coronary heart disease; $\mathrm{CKD}=$ chronic kidney disease; $\mathrm{DM}=$ diabetes mellitus; $\mathrm{HF}=$ heart failure; $\mathrm{TIA}=$ transient ischemic attack. and clinical importance of each indicator is reflected on the maximum number of points attributed to $i{ }^{25}$ and practice remuneration is calculated on the total number of points achieved across all domains. ${ }^{22}$ In 2012 to 2013, each point was worth $£ 125$ (approximately \$200). As for reported achievement, we used logit transformation to better account for the shape of the distribution and floor and ceiling effects.

\section{Statistical Analysis}

We used linear regression analyses to model the association between quality of diabetes care and prevalence of chronic conditions. We initially carried out univariate analyses with each prevalence rate (empirical logit transformation, Supplemental Appendix 1, available at http://www.annfammed.org/content/13/6/514/suppl/DC1). The 2 overall measures (process and intermediate outcomes) were then obtained by calculating separately the arithmetic mean of the logit-transformed achievement rates of the corresponding indicators in each set.

We also considered an alternative quality of care outcome, the total number of achieved points, and analyzed this outcome as a sensitivity. The complexity as a single predictor, followed by unadjusted multiple analyses, and we then adjusted for potential confounders previously identified in the literature (age, sex, list size, ethnicity, deprivation, number of family physicians, Carr-Hill list size, and exception reporting rate). ${ }^{3-7,26}$

Given that the ability of practices to develop economies of scale in the management of concordant conditions may be determined by their size, we stratified our analysis by practice size (practices with $\leq 3,000$ patients; 3,000 to 6,$000 ; 6,001$ to 10,000 ;

Table 1. List of Indicators Used to Measure Quality of Diabetes Care

\begin{tabular}{|c|c|c|c|}
\hline Indicator & Short Name & Description (\% Patients) & Type of Indicator \\
\hline DM02 & BMI record & Whose notes record body mass index & Process of care \\
\hline DM10 & Neuropathy testing & With a record of neuropathy testing & Process of care \\
\hline DM13 & $\begin{array}{l}\text { Microalbuminuria } \\
\text { record }\end{array}$ & $\begin{array}{l}\text { Who have a record of microalbuminuria testing (except reporting for patients } \\
\text { with proteinuria) }\end{array}$ & Process of care \\
\hline DM15 & ACE inhibitor & $\begin{array}{l}\text { With a diagnosis of proteinuria or microalbuminuria who are treated with } \\
\text { ACE inhibitors (or angiotensin II receptor blockers) }\end{array}$ & Process of care \\
\hline DM18 & Influenza immunization & Who have had influenza immunization & Process of care \\
\hline DM21 & Retinal screening & Who have a record of retinal screening & Process of care \\
\hline DM22 & Renal function record & $\begin{array}{l}\text { Who have a record of estimated glomerular filtration rate or serum creati- } \\
\text { nine testing }\end{array}$ & Process of care \\
\hline DM29 & Foot risk & $\begin{array}{l}\text { With a record of foot examination and risk classification: (1) low risk (nor- } \\
\text { mal sensation, palpable pulses), (2) increased risk (neuropathy or absent } \\
\text { pulses), (3) high risk (neuropathy or absent pulses plus deformity or skin } \\
\text { changes or previous ulcer), or (4) ulcerated foot }\end{array}$ & Process of care \\
\hline DM17 & $\begin{array}{l}\text { Cholesterol } \leq 193.05 \\
\mathrm{mg} / \mathrm{dL}(\leq 5 \mathrm{mmol} / \mathrm{L})\end{array}$ & $\begin{array}{l}\text { Whose last measured total cholesterol was } 193.05 \mathrm{mg} / \mathrm{dL}(\leq 5 \mathrm{mmol} / \mathrm{L}) \text { or } \\
\text { lower }\end{array}$ & Intermediate outcome \\
\hline DM26 & $\begin{array}{l}\text { Diabetes control } \\
\qquad\left(\mathrm{HbA}_{1 \mathrm{c}}=7.5 \%\right)\end{array}$ & $\begin{array}{l}\text { In whom the last IFCC- } \mathrm{HbA}_{1 \mathrm{c}} \text { reading was } 59 \mathrm{mmol} / \mathrm{mol} \text { (equivalent to } \mathrm{HbA}_{1 \mathrm{c}} \\
\text { of } 7.5 \% \text { in DCCT-derived units) or lower }\end{array}$ & Intermediate outcome \\
\hline DM31 & $\mathrm{BP} \leq 140 / 80 \mathrm{~mm} \mathrm{Hg}$ & In whom the last blood pressure reading was $140 / 80 \mathrm{~mm} \mathrm{Hg}$ or lower & Intermediate outcome \\
\hline \multicolumn{4}{|c|}{$\begin{array}{l}\mathrm{ACE}=\text { angiotensin-converting enzyme; } \mathrm{BMI}=\text { body mass index; } \mathrm{BP}=\text { blood pressure; } \mathrm{DCCT}=\text { Diabetes Control and Complications Trial; } \mathrm{DM}=\text { diabetes mellitus; } \\
\mathrm{HbA}_{1 \mathrm{C}}=\text { glycated hemoglobin; IFCC = International Federation of Clinical Chemistry. }\end{array}$} \\
\hline \multicolumn{4}{|c|}{ Note: All indicators within the previous 15 months except for DM18 (immunization in the preceding September 1 to March 31 ). } \\
\hline
\end{tabular}


and $\geq 10,000)$. For easier interpretation, coefficient estimates quantifying the associations between predictors and the logit-transformed outcomes were backtransformed to percentages.

The fit of the models was assessed using the adjusted $R^{2}$ statistic, and violations of model assumptions were investigated using plots of residuals and fitted values. In the presence of minor violations of the model assumptions, we carried out a sensitivity analysis using bootstrap methods of 1,000 samples. Under this approach, no assumptions are made for the sampling distribution of the estimated parameters, and the obtained standard errors are considered more robust. We investigated potential collinearity by estimating the variance inflation factors (VIF) associated with all predictors. We conducted a sensitivity analysis consisting of removing and subsequently including 1 by 1 those predictors with a VIF of greater than 4 . This approach enabled us to detect potential relevant changes in the magnitude or direction of the regression coefficients caused by collinearity. ${ }^{27}$ All analyses were carried out in Stata 12.1 (StataCorp) and we used an $\alpha$ of $5 \%$ throughout.

\section{RESULTS}

\section{Characteristics of the Practices}

There were 54,220,050 patients registered with the practices in this study (mean patients per practice $=6,877, \mathrm{SD}=4,001$ ) (Table 2). The median achievement rate was $92.46 \%$ for processes of care for diabetes (interquartile range $[\mathrm{IQR}]=4.47 \%$ ) and $73.73 \%(\mathrm{IQR}=7.42 \%)$ for intermediate outcomes.

\section{Impact of the Prevalence of Conditions on the Process of Care for Diabetes}

Table 3 displays the association between the prevalence of the selected conditions and the composite measure of quality of processes of diabetes care, across all practices and by practice list size. Across all practices, the prevalence of diabetes was negatively associated with the quality of processes of care measure (back-transformed effect, $-0.31 \%)$. Thus, for a practice with an average achievement rate, a relative increase of $1 \%$ in the prevalence of diabetes was associated with a $0.31 \%$ higher achievement rate across the overall processes of care.

Four of the 7 diabetes-concordant conditions were positively associated with our measure of quality of process of care, including obesity $(0.33 \%)$, chronic kidney disease $(0.18 \%)$, atrial fibrillation $(0.57 \%)$, and heart failure $(0.60 \%)$. No association was observed for stroke or transient ischemic attack, and a negative association was observed for both hypertension $(-0.08 \%)$ and coronary heart disease $(-0.38 \%)$.
Table 2. Characteristics of the Practices Included in the Study $(\mathrm{N}=7,884)$

\begin{tabular}{|c|c|c|}
\hline Characteristic & Mean (SD) & Range \\
\hline Registered patients, No. & $6,877(4,001)$ & $572-37,474$ \\
\hline Female patients, \% & $50.16(6.08)$ & $8.64-75.85$ \\
\hline \multicolumn{3}{|l|}{ Patient age ranges } \\
\hline $18-24$ y, \% & $9.82(5.91)$ & $0-91.65$ \\
\hline $25-34$ y, \% & $17.50(8.46)$ & $0-71.15$ \\
\hline $35-44 y, \%$ & $18.02(5.63)$ & $0-45.09$ \\
\hline $45-54$ y, \% & $18.47(4.30)$ & $0-42.38$ \\
\hline $55-64$ y, \% & $14.76(4.42)$ & $0-32.54$ \\
\hline $65-74 y_{1} \%$ & $11.70(4.71)$ & $0-30.00$ \\
\hline $75-84$ y, \% & $6.98(3.13)$ & $0-22.21$ \\
\hline$\geq 85$ y & $2.74(1.65)$ & $0-14.41$ \\
\hline \multicolumn{3}{|l|}{ Ethnicity } \\
\hline White, \% & $84.15(21.72)$ & $0-100$ \\
\hline Asian, \% & $7.98(14.00)$ & $0-87.48$ \\
\hline Black, \% & $3.28(6.41)$ & $0-59.07$ \\
\hline $\begin{array}{l}\text { Index of multiple deprivation } \\
\text { score }\end{array}$ & 21.78 & 18.54 \\
\hline Prevalence of diabetes, $\%$ & $6.21(1.77)$ & $0.10-18.00$ \\
\hline \multicolumn{3}{|l|}{$\begin{array}{l}\text { Prevalence of diabetes-concordant } \\
\text { conditions }\end{array}$} \\
\hline Obesity, \% & $11.25(3.83)$ & $0-43.30$ \\
\hline Hypertension, \% & $13.81(3.67)$ & $0-36.10$ \\
\hline CHD, \% & $3.34(1.17)$ & $0-9.10$ \\
\hline CKD, \% & $4.16(2.08)$ & $0-24.10$ \\
\hline Stroke and TIA, \% & $1.66(0.65)$ & $0-6.50$ \\
\hline Atrial fibrillation, \% & $1.45(0.66)$ & $0-5.10$ \\
\hline Heart failure, $\%$ & $0.71(0.33)$ & $0-3.90$ \\
\hline \multicolumn{3}{|l|}{$\begin{array}{l}\text { Prevalence of diabetes-discordant } \\
\text { conditions }\end{array}$} \\
\hline Asthma, \% & $5.95(1.36)$ & $0-13.70$ \\
\hline Cancer, \% & $1.87(0.74)$ & $0-5.50$ \\
\hline COPD, \% & $1.79(0.89)$ & $0-8.20$ \\
\hline Dementia, \% & $0.55(0.39)$ & $0-9.60$ \\
\hline Depression, \% & $5.78(3.01)$ & $0-35.90$ \\
\hline Epilepsy, \% & $0.78(0.28)$ & $0-4.00$ \\
\hline Hypothyroidism, \% & $3.17(1.05)$ & $0.10-8.50$ \\
\hline Severe mental health disorders, $\%$ & $0.87(0.45)$ & $0-11.80$ \\
\hline
\end{tabular}

Two of 8 diabetes-discordant conditions were negatively associated with quality of process of care: epilepsy $(-0.80 \%)$ and severe mental health disorders $(-0.76 \%)$. No associations were observed for 3 other discordant conditions (dementia, depression, and hypothyroidism), whereas positive associations were observed for asthma $(0.19 \%)$, cancer $(0.59 \%)$, and COPD (0.23\%).

\section{Impact of the Prevalence of Conditions on Intermediate Outcomes}

Table 4 shows the association between the prevalence of the selected conditions and the composite 
Table 3. Association Between Quality of Diabetes Care (Process) and the Prevalence of Diabetes and Diabetes-Concordant and Diabetes-Discordant Conditions

\begin{tabular}{|c|c|c|c|c|c|}
\hline Condition & $\begin{array}{c}<3,000 \\
\text { Patients } \\
(\mathrm{n}=1,376) \\
\%(95 \% \mathrm{Cl})\end{array}$ & $\begin{array}{c}3,000-6,000 \\
\text { Patients } \\
(n=2,466) \\
\%(95 \% \mathrm{Cl})\end{array}$ & $\begin{array}{c}6,001-10,000 \\
\text { Patients } \\
(n=2,354) \\
\%(95 \% \mathrm{Cl})\end{array}$ & $\begin{array}{c}>10,000 \\
\text { Patients } \\
(n=1,688) \\
\%(95 \% \mathrm{Cl})\end{array}$ & $\begin{array}{l}\text { All Practices } \\
(\mathrm{N}=7,884) \\
\%(95 \% \mathrm{Cl})\end{array}$ \\
\hline Diabetes & $\begin{array}{c}-0.32 \\
(-0.57 \text { to }-0.07)^{a}\end{array}$ & $\begin{array}{c}-0.23 \\
(-0.41 \text { to }-0.05)^{\mathrm{a}}\end{array}$ & $\begin{array}{c}-0.26 \\
(-0.44 \text { to }-0.08)^{\mathrm{a}}\end{array}$ & $\begin{array}{c}-0.54 \\
(-0.78 \text { to }-0.29)\end{array}$ & $\begin{array}{c}-0.31 \\
(-0.41 \text { to }-0.21)^{\mathrm{a}}\end{array}$ \\
\hline \multicolumn{6}{|l|}{ Diabetes concordant } \\
\hline Obesity & $\begin{array}{c}0.37 \\
(0.29 \text { to } 0.44)^{a}\end{array}$ & $\begin{array}{c}0.31 \\
(0.26 \text { to } 0.38)^{\mathrm{a}}\end{array}$ & $\begin{array}{c}0.35 \\
(0.30 \text { to } 0.41)^{\mathrm{a}}\end{array}$ & $\begin{array}{c}0.27 \\
(0.20 \text { to } 0.35)^{\mathrm{a}}\end{array}$ & $\begin{array}{c}0.33 \\
(0.30 \text { to } 0.37)^{\mathrm{a}}\end{array}$ \\
\hline Hypertension & $\begin{array}{c}-0.13 \\
(-0.26 \text { to }-0.01)^{a}\end{array}$ & $\begin{array}{c}-0.10 \\
(-0.20 \text { to } 0.00)\end{array}$ & $\begin{array}{c}-0.11 \\
(-0.20 ;-0.01)^{\mathrm{a}}\end{array}$ & $\begin{array}{c}0.09 \\
(-0.03 \text { to }-0.21)^{\mathrm{a}}\end{array}$ & $\begin{array}{c}-0.08 \\
(-0.13 \text { to }-0.02)^{\mathrm{a}}\end{array}$ \\
\hline CHD & $\begin{array}{c}-0.31 \\
(-0.77 \text { to } 0.14)\end{array}$ & $\begin{array}{c}-0.54 \\
(-0.92 \text { to }-0.20)^{\mathrm{a}}\end{array}$ & $\begin{array}{c}-0.09 \\
(-0.43 \text { to } 0.24)\end{array}$ & $\begin{array}{c}-0.38 \\
(-0.84 \text { to } 0.05)\end{array}$ & $\begin{array}{c}-0.38 \\
(-0.58 \text { to }-0.20)^{a}\end{array}$ \\
\hline CKD & $\begin{array}{c}0.29 \\
(0.14 \text { to } 0.45)^{a}\end{array}$ & $\begin{array}{c}0.21 \\
(0.10 \text { to } 0.33)^{a}\end{array}$ & $\begin{array}{c}0.07 \\
(-0.02 \text { to } 0.17)\end{array}$ & $\begin{array}{c}0.21 \\
(0.09 \text { to } 0.32)^{a}\end{array}$ & $\begin{array}{c}0.18 \\
(0.12 \text { to } 0.24)^{\mathrm{a}}\end{array}$ \\
\hline Stroke and TIA & $\begin{array}{c}0.81 \\
(0.05 \text { to } 1.50)^{\mathrm{a}}\end{array}$ & $\begin{array}{c}-0.30 \\
(-0.97 \text { to } 0.32)\end{array}$ & $\begin{array}{c}0.35 \\
(-0.26 \text { to } 0.91)\end{array}$ & $\begin{array}{c}0.28 \\
(-0.53 \text { to } 1.03)\end{array}$ & $\begin{array}{c}0.28 \\
(-0.05 \text { to } 0.60)\end{array}$ \\
\hline Atrial fibrillation & $\begin{array}{c}-0.38 \\
(-1.29 \text { to } 0.45)\end{array}$ & $\begin{array}{c}0.87 \\
(0.30 \text { to } 1.46)^{a}\end{array}$ & $\begin{array}{c}1.25 \\
(0.71 \text { to } 1.76)^{\mathrm{a}}\end{array}$ & $\begin{array}{c}0.62 \\
(-0.13 \text { to } 1.31)\end{array}$ & $\begin{array}{c}0.57 \\
(0.25 \text { to } 0.89)^{\mathrm{a}}\end{array}$ \\
\hline Heart failure & $\begin{array}{c}0.89 \\
(-0.10 \text { to } 1.78)\end{array}$ & $\begin{array}{c}0.59 \\
(-0.13 \text { to } 1.30)\end{array}$ & $\begin{array}{c}0.40 \\
(-0.31 \text { to } 1.06)\end{array}$ & $\begin{array}{c}0.44 \\
(-0.51 \text { to } 1.29)\end{array}$ & $\begin{array}{c}0.60 \\
(0.25 \text { to } 0.89)^{\mathrm{a}}\end{array}$ \\
\hline \multicolumn{6}{|l|}{ Diabetes discordant } \\
\hline Asthma & $\begin{array}{c}0.09 \\
(-0.13 \text { to } 0.30)\end{array}$ & $\begin{array}{c}0.30 \\
(0.15 \text { to } 0.46)^{a}\end{array}$ & $\begin{array}{c}0.01 \\
(-0.14 \text { to } 0.16)\end{array}$ & $\begin{array}{c}0.32 \\
(0.13 \text { to } 0.51)^{\mathrm{a}}\end{array}$ & $\begin{array}{c}0.19 \\
(0.10 \text { to } 0.27)^{\mathrm{a}}\end{array}$ \\
\hline Cancer & $\begin{array}{c}1.05 \\
(0.49 \text { to } 1.59)^{\mathrm{a}}\end{array}$ & $\begin{array}{c}0.70 \\
(0.29 \text { to } 1.13)^{\mathrm{a}}\end{array}$ & $\begin{array}{c}0.10 \\
(-0.32 \text { to } 0.50)\end{array}$ & $\begin{array}{c}0.41 \\
(-0.04 \text { to } 0.85)\end{array}$ & $\begin{array}{c}0.59 \\
(0.37 \text { to } 0.81)^{\mathrm{a}}\end{array}$ \\
\hline COPD & $\begin{array}{c}0.29 \\
(-0.14 \text { to } 0.70)\end{array}$ & $\begin{array}{c}0.26 \\
(-0.06 \text { to } 0.59)\end{array}$ & $\begin{array}{c}0.06 \\
(-0.28 \text { to } 0.38)\end{array}$ & $\begin{array}{c}0.19 \\
(-0.26 \text { to } 0.62)\end{array}$ & $\begin{array}{c}0.23 \\
(0.05 \text { to } 0.41)^{\mathrm{a}}\end{array}$ \\
\hline Dementia & $\begin{array}{c}-0.11 \\
(-0.83 \text { to } 0.56)\end{array}$ & $\begin{array}{c}0.28 \\
(-0.24 \text { to } 0.78)\end{array}$ & $\begin{array}{c}-0.15 \\
(-0.83 \text { to } 0.48)\end{array}$ & $\begin{array}{c}-0.62 \\
(-1.52 \text { to } 0.21)\end{array}$ & $\begin{array}{c}0.01 \\
(-0.30 \text { to } 0.31)\end{array}$ \\
\hline Depression & $\begin{array}{c}-0.02 \\
(-0.12 \text { to } 0.08)\end{array}$ & $\begin{array}{c}-0.05 \\
(-0.12 \text { to } 0.02)\end{array}$ & $\begin{array}{c}-0.03 \\
(-0.09 \text { to } 0.03)\end{array}$ & $\begin{array}{c}0.01 \\
(-0.06 \text { to } 0.09)\end{array}$ & $\begin{array}{c}-0.03 \\
(-0.07 \text { to } 0.01)\end{array}$ \\
\hline Epilepsy & $\begin{array}{c}0.12 \\
(-0.90 \text { to } 1.05)\end{array}$ & $\begin{array}{c}-0.77 \\
(-1.75 \text { to } 0.08)\end{array}$ & $\begin{array}{c}-1.07 \\
(-2.07 \text { to }-0.15)^{\mathrm{a}}\end{array}$ & $\begin{array}{c}-1.65 \\
(-3.06 \text { to }-0.39)^{\mathrm{a}}\end{array}$ & $\begin{array}{c}-0.80 \\
(-1.30 \text { to }-0.33)^{\mathrm{a}}\end{array}$ \\
\hline Hypothyroidism & $\begin{array}{c}0.06 \\
(-0.28 \text { to } 0.38)\end{array}$ & $\begin{array}{c}0.19 \\
(-0.05 \text { to } 0.45)\end{array}$ & $\begin{array}{c}0.07 \\
(-0.17 \text { to } 0.31)\end{array}$ & $\begin{array}{c}-0.06 \\
(-0.35 \text { to } 0.22)\end{array}$ & $\begin{array}{c}0.08 \\
(-0.05 \text { to } 0.22)\end{array}$ \\
\hline $\begin{array}{l}\text { Severe mental } \\
\text { health disorder }\end{array}$ & $\begin{array}{c}-0.85 \\
(-1.42 \text { to }-0.31)^{\mathrm{a}}\end{array}$ & $\begin{array}{c}-1.16 \\
(-1.82 \text { to }-0.62)^{\mathrm{a}}\end{array}$ & $\begin{array}{c}-0.42 \\
(-0.99 \text { to } 0.12)\end{array}$ & $\begin{array}{c}-0.45 \\
(-1.27 \text { to } 0.31)\end{array}$ & $\begin{array}{c}-0.76 \\
(-1.04 \text { to }-0.49)^{\mathrm{a}}\end{array}$ \\
\hline
\end{tabular}

$\mathrm{CHD}=$ coronary heart disease; $\mathrm{CKD}=$ chronic kidney disease; COPD = chronic obstructive pulmonary disease; TIA = transient ischemic attack.

Note: Based on multivariate linear regression analysis. Dependent variable is the logit-transformed achievement rate of processes of care indicators. Independent variables are the prevalence of diabetes and conditions concordant and discordant to diabetes. Analysis adjusted for age, sex, ethnicity, deprivation, number of general practitioners, Carr-Hill list size, and exception rate. Coefficients have been back-transformed to percentages from logit-transformed achievement rates. $\beta$ is the fully adjusted, absolute percentage change in achievement rate across the overall processes of care, per $1 \%$ change in prevalence.

${ }^{a} P<.05$.

measure of diabetes intermediate outcomes. Diabetes prevalence was not associated with the intermediate outcomes measure $(-0.06 \%)$. Positive associations with the intermediate outcomes measure were observed again for the same 4 diabetes-concordant conditions, including obesity $(0.24 \%)$, chronic kidney disease $(0.30 \%)$, atrial fibrillation $(0.97 \%)$, and heart failure $(0.98 \%)$, whereas negative associations were observed again for hypertension $(-0.22 \%)$ and coronary heart disease $(-0.31 \%)$, and no association was observed for stroke or transient ischemic attack.

With respect to the discordant conditions, negative associations with the intermediate outcomes measure were observed similarly for epilepsy $(-1.58 \%)$ and severe mental health problems $(-0.95 \%)$. No associations were observed for asthma, dementia, depression, and hypothyroidism. Positive associations were observed for cancer $(0.89 \%)$ and COPD (0.95\%).

Both for processes of care and intermediate outcomes, stratified analyses by practice list size showed a pattern of associations similar to the overall models.

\section{Sensitivity Analyses}

The fully adjusted multivariable models explained $28 \%$ and $29 \%$ of the variation in our measures of processes of care and intermediate outcomes. On inspection of residual plots, the assumption of normally distributed residuals with constant variance appeared to be vio- 
Table 4. Association Between the Quality of Diabetes Care (Intermediate Outcomes) and the Prevalence of Diabetes and Diabetes-Concordant and Diabetes-Discordant Conditions

\begin{tabular}{|c|c|c|c|c|c|}
\hline Condition & $\begin{array}{c}<3,000 \text { Patients } \\
(\mathrm{n}=1,376) \\
\%(95 \% \mathrm{Cl})\end{array}$ & $\begin{array}{c}3,000 \text { to } 6,000 \\
\text { Patients } \\
(n=2,466) \\
\%(95 \% \mathrm{Cl})\end{array}$ & $\begin{array}{c}6,001 \text { to } 10,000 \\
\text { Patients } \\
(\mathrm{n}=2,354) \\
\%(95 \% \mathrm{Cl})\end{array}$ & $\begin{array}{c}>10,000 \\
\text { Patients } \\
(\mathrm{n}=1,688) \\
\%(95 \% \mathrm{Cl})\end{array}$ & $\begin{array}{l}\text { All Practices } \\
(\mathrm{N}=7,884) \\
\%(95 \% \mathrm{Cl})\end{array}$ \\
\hline Diabetes & $\begin{array}{c}0.06 \\
(-0.32 \text { to }-0.44)\end{array}$ & $\begin{array}{c}0.04 \\
(-0.22 \text { to } 0.31)\end{array}$ & $\begin{array}{c}0.08 \\
(-0.22 \text { to } 0.36)\end{array}$ & $\begin{array}{c}0.25 \\
(-0.11 \text { to } 0.60)\end{array}$ & $\begin{array}{c}0.06 \\
(-0.09 \text { to } 0.22)\end{array}$ \\
\hline \multicolumn{6}{|l|}{ Diabetes concordant } \\
\hline Obesity & $\begin{array}{c}0.27 \\
(0.15 \text { to } 0.39)^{\mathrm{a}}\end{array}$ & $\begin{array}{c}0.27 \\
(0.18 \text { to } 0.36)^{a}\end{array}$ & $\begin{array}{c}0.28 \\
(0.18 \text { to } 0.37)^{\mathrm{a}}\end{array}$ & $\begin{array}{c}0.08 \\
(-0.04 \text { to } 0.20)\end{array}$ & $\begin{array}{c}0.24 \\
(0.19 \text { to } 0.29)^{\mathrm{a}}\end{array}$ \\
\hline Hypertension & $\begin{array}{c}-0.21 \\
(-0.40 \text { to }-0.02)^{a}\end{array}$ & $\begin{array}{c}-0.23 \\
(-0.37 \text { to }-0.08)^{a}\end{array}$ & $\begin{array}{c}-0.33 \\
(-0.49 \text { to }-0.18)^{\mathrm{a}}\end{array}$ & $\begin{array}{c}-0.22 \\
(-0.40 \text { to }-0.04)^{\mathrm{a}}\end{array}$ & $\begin{array}{c}-0.22 \\
(-0.30 \text { to }-0.14)^{\mathrm{a}}\end{array}$ \\
\hline CHD & $\begin{array}{c}-0.28 \\
(-0.97 \text { to } 0.40)\end{array}$ & $\begin{array}{c}-0.43 \\
(-0.93 \text { to } 0.07)\end{array}$ & $\begin{array}{c}0.09 \\
(-0.45 \text { to } 0.62)\end{array}$ & $\begin{array}{c}-0.20 \\
(-0.86 \text { to } 0.45)\end{array}$ & $\begin{array}{c}-0.31 \\
(-0.59 \text { to }-0.02)^{\mathrm{a}}\end{array}$ \\
\hline CKD & $\begin{array}{c}0.36 \\
(0.11 \text { to } 0.60)^{\mathrm{a}}\end{array}$ & $\begin{array}{c}0.30 \\
(0.13 \text { to } 0.47)^{\mathrm{a}}\end{array}$ & $\begin{array}{c}0.26 \\
(0.10 \text { to } 0.41)^{a}\end{array}$ & $\begin{array}{c}0.32 \\
(0.15 \text { to } 0.50)^{a}\end{array}$ & $\begin{array}{c}0.30 \\
(0.21 \text { to } 0.39)^{a}\end{array}$ \\
\hline Stroke and TIA & $\begin{array}{c}0.28 \\
(-0.94 \text { to } 1.48)\end{array}$ & $\begin{array}{c}-0.15 \\
(-1.07 \text { to } 0.76)\end{array}$ & $\begin{array}{c}0.11 \\
(-0.89 \text { to } 1.08)\end{array}$ & $\begin{array}{c}0.53 \\
(-0.71 \text { to } 1.72)\end{array}$ & $\begin{array}{c}0.14 \\
(-0.37 \text { to } 0.65)\end{array}$ \\
\hline Atrial fibrillation & $\begin{array}{c}-0.57 \\
(-1.90 \text { to } 0.72)\end{array}$ & $\begin{array}{c}1.30 \\
(0.38 \text { to } 2.19)^{a}\end{array}$ & $\begin{array}{c}2.39 \\
(1.45 \text { to } 3.32)^{a}\end{array}$ & $\begin{array}{c}1.17 \\
(0.02 \text { to } 2.29)^{\mathrm{a}}\end{array}$ & $\begin{array}{c}0.97 \\
(0.46 \text { to } 1.48)^{\mathrm{a}}\end{array}$ \\
\hline Heart failure & $\begin{array}{c}1.19 \\
(-0.39 \text { to } 2.71)\end{array}$ & $\begin{array}{c}1.30 \\
(0.21 \text { to } 2.36)^{a}\end{array}$ & $\begin{array}{c}-0.26 \\
(-1.45 \text { to } 0.90)\end{array}$ & $\begin{array}{c}1.42 \\
(0.01 \text { to } 2.77)^{\mathrm{a}}\end{array}$ & $\begin{array}{c}0.98 \\
(0.36 \text { to } 1.60)^{\mathrm{a}}\end{array}$ \\
\hline \multicolumn{6}{|l|}{ Diabetes discordant } \\
\hline Asthma & $\begin{array}{c}-0.22 \\
(-0.55 \text { to } 0.11)\end{array}$ & $\begin{array}{c}0.18 \\
(-0.05 \text { to } 0.42)\end{array}$ & $\begin{array}{c}-0.26 \\
(-0.51 \text { to }-0.01)^{\mathrm{a}}\end{array}$ & $\begin{array}{c}0.01 \\
(-0.29 \text { to } 0.30)\end{array}$ & $\begin{array}{c}-0.07 \\
(-0.20 \text { to } 0.07)\end{array}$ \\
\hline Cancer & $\begin{array}{c}2.01 \\
(1.09 \text { to } 2.91)^{\mathrm{a}}\end{array}$ & $\begin{array}{c}0.81 \\
(0.16 \text { to } 1.46)^{\mathrm{a}}\end{array}$ & $\begin{array}{c}0.22 \\
(-0.46 \text { to } 0.89)\end{array}$ & $\begin{array}{c}0.56 \\
(-0.14 \text { to } 1.26)\end{array}$ & $\begin{array}{c}0.89 \\
(0.53 \text { to } 1.25)^{\mathrm{a}}\end{array}$ \\
\hline COPD & $\begin{array}{c}0.99 \\
(0.33 \text { to } 1.64)^{\mathrm{a}}\end{array}$ & $\begin{array}{c}0.85 \\
(0.38 \text { to } 1.33)^{\mathrm{a}}\end{array}$ & $\begin{array}{c}0.89 \\
(0.36 \text { to } 1.42)^{\mathrm{a}}\end{array}$ & $\begin{array}{c}1.12 \\
(0.45 \text { to } 1.78)^{\mathrm{a}}\end{array}$ & $\begin{array}{c}0.95 \\
(0.68 \text { to } 1.23)^{\mathrm{a}}\end{array}$ \\
\hline Dementia & $\begin{array}{c}0.38 \\
(-0.69 \text { to } 1.42)\end{array}$ & $\begin{array}{c}0.42 \\
(-0.34 \text { to } 1.18)\end{array}$ & $\begin{array}{c}-0.09 \\
(-1.16 \text { to } 0.95)\end{array}$ & $\begin{array}{c}-0.63 \\
(-1.91 \text { to } 0.61)\end{array}$ & $\begin{array}{c}0.17 \\
(-0.30 \text { to } 0.64)\end{array}$ \\
\hline Depression & $\begin{array}{c}0.10 \\
(-0.05 \text { to } 0.24)\end{array}$ & $\begin{array}{c}-0.05 \\
(-0.15 \text { to } 0.05)\end{array}$ & $\begin{array}{c}0.08 \\
(-0.02 \text { to } 0.18)\end{array}$ & $\begin{array}{c}0.05 \\
(-0.06 \text { to } 0.16)\end{array}$ & $\begin{array}{c}0.03 \\
(-0.03 \text { to } 0.08)\end{array}$ \\
\hline Epilepsy & $\begin{array}{c}0.39 \\
(-1.15 \text { to } 1.87)\end{array}$ & $\begin{array}{c}-2.46 \\
(-3.78 \text { to }-1.18)^{\mathrm{a}}\end{array}$ & $\begin{array}{c}-1.74 \\
(-3.23 \text { to }-0.30)^{\mathrm{a}}\end{array}$ & $\begin{array}{c}-2.97 \\
(-4.86 \text { to }-1.14)^{\mathrm{a}}\end{array}$ & $\begin{array}{c}-1.58 \\
(-2.30 \text { to }-0.87)^{\mathrm{a}}\end{array}$ \\
\hline Hypothyroidism & $\begin{array}{c}0.33 \\
(-0.18 \text { to } 0.85)\end{array}$ & $\begin{array}{c}0.28 \\
(-0.09 \text { to } 0.65)\end{array}$ & $\begin{array}{c}-0.16 \\
(-0.56 \text { to } 0.24)\end{array}$ & $\begin{array}{c}-0.08 \\
(-0.52 \text { to } 0.36)\end{array}$ & $\begin{array}{c}0.13 \\
(-0.08 \text { to } 0.34)\end{array}$ \\
\hline $\begin{array}{l}\text { Severe mental } \\
\text { health disorder }\end{array}$ & $\begin{array}{c}-1.76 \\
(-2.58 \text { to }-0.95)^{\mathrm{a}}\end{array}$ & $\begin{array}{c}-0.54 \\
(-1.34 \text { to } 0.24)\end{array}$ & $\begin{array}{c}-0.04 \\
(-0.91 \text { to } 0.82)\end{array}$ & $\begin{array}{c}-1.06 \\
(-2.25 \text { to } 0.11)\end{array}$ & $\begin{array}{c}-0.95 \\
(-1.35 \text { to }-0.56)^{\mathrm{a}}\end{array}$ \\
\hline
\end{tabular}

$\mathrm{CHD}=$ coronary heart disease; CKD = chronic kidney disease; COPD = chronic obstructive pulmonary disease; TIA = transient ischemic attack.

Note: Based on multivariate linear regression analysis. Dependent variable is the logit-transformed achievement rate of intermediate outcomes indicators. Independent variables are the prevalence of diabetes and conditions concordant and discordant to diabetes. Analysis adjusted for age, sex, ethnicity, deprivation, number of general practitioners, Carr-Hill list size, and exception rate. Coefficients have been back-transformed to percentages from logit-transformed achievement rates. $\beta$ is the fully adjusted, absolute percentage change in achievement rate across the overall intermediate outcomes, per $1 \%$ change in prevalence.

a $P<.05$.

lated. The implications were further studied in our sensitivity analyses.

Results obtained from our first sensitivity analysis (bootstrap approach) did not differ from the main analysis results. Similarly, our second sensitivity analysis based on an alternative measure of quality of care (QOF points) produced results similar to those of the main analysis (Supplemental Appendices 2 and 3, available at http:// www.annfammed.org/content/13/6/514/suppl/DC1). The main exception was the prevalence of diabetes, which was positively (rather than negatively) associated with processes of care. Differences that were also observed for other associations (around 30\%) did not affect their direction, but rather their statistical significance.
Our final sensitivity analysis confirmed that regression coefficients remained stable after we first removed and subsequently included, 1 by 1,4 predictors identified as having higher VIFs.

\section{DISCUSSION}

The prevalence of most chronic conditions examined in this study was associated with the quality of care for diabetes after adjustment for established key predictors of quality at the practice level. These associations were largely consistent across processes and outcomes of care, but the direction of the associations could not be fully explained by the concordant or discordant nature 
of the conditions. Although the prevalence of most concordant conditions was associated with higher quality of care, contrary to the hypotheses, the prevalence of hypertension and coronary heart failure were negatively associated with both processes and intermediate outcomes of care for diabetes. A mixed picture of associations was observed for discordant conditions, including strong positive associations for cancer and COPD.

\section{Diabetes Prevalence}

Previous studies have identified a number of practicelevel characteristics that could influence diabetes care. ${ }^{3.7}$ A volume-outcome relationship has also been suggested for diabetes care in family practices, although evidence is inconclusive. ${ }^{5,8,9}$

The observation that the practice-level prevalence of diabetes is associated with a lower quality of process of care as measured by our composite indicator, although perhaps counterintuitive, is actually consistent with previous research. ${ }^{9,28}$ This finding may be attributable to residual confounding on account of socioeconomic status of the practice population, which could also explain the similar patterns of associations observed in such conditions as epilepsy or mental health disorders, which tend to be more common in more deprived areas. ${ }^{29,30}$ No association was observed between the prevalence of diabetes and intermediate outcomes, which might reflect that intermediate outcomes are the result of not only the medical care provided, but also of other factors, such as patients' adherence to medication and lifestyle recommendations.

Our sensitivity analyses based on QOF points rather than achievement scores revealed some differences from the main analysis, most notably a reversal in the direction of the association between process of care and the prevalence of diabetes. These differences could be explained from an organizational perspective if practices with a higher proportion of patients with diabetes are more responsive to financial rewards related to diabetes care, as previously suggested by Kontopantelis et al. ${ }^{3}$

\section{Prevalence of Concordant and Discordant Conditions}

The practice prevalence of most chronic conditions was associated with quality of care. Some associations, although statistically significant, were relatively weak. For example, even a relative difference of $10 \%$ in diabetes prevalence was associated with only a $3.6 \%$ higher quality process of diabetes care-a relatively small effect. Some other conditions, however (atrial fibrillation, heart failure, cancer, COPD, epilepsy and mental disorders), were more strongly associated with our measures of quality of care.
We had hypothesized that the pattern of associations predicted by the concordant-discordant model might operate at an organizational level, with practices responding to the specific nature of the morbidity burden of their practice population. Although our observations do not confirm this hypothesis, observed levels of departure from the model were different for concordant and discordant conditions. It is because concordant conditions were broadly in accordance with the proposed model that the negative associations for hypertension and coronary heart failure are more difficult to explain. Speculation based on ad hoc explanations for this overall mixed picture does not appear to be justified.

The key observation is that, when measured at the practice level, disease prevalence of a great number of chronic conditions is associated with quality of diabetes care and that the concordant-discordant model does not seem to explain the observed patterns.

\section{Future Research and Implications for Health Services Organization}

This study is the first to be conducted at the practice level, and replication of findings with other data sources, ideally in other countries, would be desirable before our findings can be used to inform policy. If confirmed, however, our observations would suggest that prevalence of a number of chronic conditions can be a predictor of quality of care of diabetes. Incentive programs (financial or otherwise) should consider the number of chronic conditions when assessing performance of individual clinicians.

Different factors could contribute to the observed associations, and the mechanisms by which these associations operate remain to be identified. Specifically, practice characteristics at the interface between structure and process of care (such as, specialized nurses and physician associates or assistants, specialized clinics, community outreach programs) and potentially increased opportunities for patient peer support in communities with high rates of concordant conditions should be prioritized. In addition, service utilization is a known mediator of the relationship between morbidity burden and quality of care, because patients with comorbid conditions tend to be more frequent service users and are thus exposed to more opportunities for their care needs to be met. ${ }^{31,32}$ To increase our understanding in this area, multilevel analyses at the patient level are needed. These analyses would benefit from a number of repeated measurements of both prevalence of the conditions and quality of diabetes care, while considering sources of variation at the patient, the primary or named physician, the practice, and potentially higher organizational levels. Secondary analyses of 
available cohort studies of patients with diabetes may offer an efficient approach to further study this issue.

\section{Strengths and Limitations}

Although our study included data for most practices in England, and we used robust analytic methods, it has some limitations. First, the cross-sectional nature of this study makes causal inference problematic. It is implausible that quality of diabetes care may have affected the prevalence of discordant conditions. For concordant conditions, however, current quality of diabetes care might be a valid proxy for previous quality, which may have helped to prevent the development of some concordant conditions. Second, we measured quality of diabetes care based on practice-reported information, which may differ from actual care. Data were extracted from clinical records, however, increasing the confidence in their validity. Third, the indicators used to measure quality of diabetes care represent only a proportion of the health care provided by a practice to patients with diabetes. The nature, scope, and evidence base of the activities included, however, makes it unlikely that this limitation may have introduced any major bias. Fourth, our regression models explained a relatively low percentage of the variation in our composite measures of quality of diabetes care (between 28\% and 29\%). Although we controlled for practice-level variables previously identified, other potentially relevant confounders were not included, especially patient-level characteristics, such as self-management behavior, medication adherence, or service use. Examining the role of patient-level characteristics was outside the scope of this practice-level analysis, a first step in investigating the concordantdiscordant model. Future work, however, should focus on patient-level data and fully evaluate the role of patient and practice covariates.

The concordant-discordant model does not explain the patterns of association between the prevalence of chronic conditions and the quality of diabetes care provided by family practices in England. Even so, the strength of the associations and their consistency across different types of practices, quality of care domains, and measures support the validity of our findings.

To read or post commentaries in response to this article, see it online at http://www.annfammed.org/content/13/6/514.

Key words: health care delivery/HSR: quality of care; endocrinology: diabetes; chronic care: comorbidity/multimorbidity; primary health care

Submitted January 26, 2015; submitted, revised, June 12, 2015; accepted July 10, 2015.

Acknowledgments: The authors thank Martin Roland (Cambridge University) and Hugh Gravelle (University of York) for helpful comments on the manuscript, and Suzanne Griffiths for proofreading the final version of the manuscript.

- Supplementary materials: Available at http://www.AnnFamMed. org/content/13/6/514/suppl/DC1/.

\section{References}

1. Morse A; Department of Health. The management of adult diabetes services in the NHS. http://www.nao.org.uk/wp-content/ uploads/2012/05/121321.pdf. Published May 23, 2012. Accessed Jun 12, 2015.

2. Hawthorne G, Hrisos S, Stamp E, et al. Diabetes care provision in UK primary care practices. PLoS One. 2012;7(7):e41562.

3. Kontopantelis E, Reeves D, Valderas JM, Campbell S, Doran T. Recorded quality of primary care for patients with diabetes in England before and after the introduction of a financial incentive scheme: a longitudinal observational study. BMJ Qual Saf. 2013; 22(1):53-64.

4. Khunti K, Ganguli S, Baker R, Lowy A. Features of primary care associated with variations in process and outcome of care of people with diabetes. Br J Gen Pract. 2001;51(466):356-360.

5. Millett C, Car J, Eldred D, Khunti K, Mainous AG III, Majeed A. Diabetes prevalence, process of care and outcomes in relation to practice size, caseload and deprivation: national cross-sectional study in primary care. J R Soc Med. 2007;100(6):275-283.

6. Saxena S, Car J, Eldred D, Soljak M, Majeed A. Practice size, caseload, deprivation and quality of care of patients with coronary heart disease, hypertension and stroke in primary care: national crosssectional study. BMC Health Serv Res. 2007;7:96.

7. Schaars CF, Denig P, Kasje WN, Stewart RE, Wolffenbuttel BHR, Haaijer-Ruskamp FM. Physician, organizational, and patient factors associated with suboptimal blood pressure management in type 2 diabetic patients in primary care. Diabetes Care. 2004;27(1):123-128.

8. Holmboe ES, Wang Y, Tate JP, Meehan TP. The effects of patient volume on the quality of diabetic care for Medicare beneficiaries. Med Care. 2006;44(12):1073-1077.

9. Turchin A, Shubina M, Pendergrass ML. Relationship of physician volume with process measures and outcomes in diabetes. Diabetes Care. 2007;30(6):1442-1447.

10. Valderas JM, Starfield B, Sibbald B, Salisbury C, Roland M. Defining comorbidity: implications for understanding health and health services. Ann Fam Med. 2009;7(4):357-363.

11. Piette JD, Kerr EA. The impact of comorbid chronic conditions on diabetes care. Diabetes Care. 2006;29(3):725-731.

12. NHS England Analytical Services (Finance). Technical Guide to the formulae for 2014-15 and 2015-16 revenue allocations to Clinical Commissioning Groups and Area Teams, 2014. http://www.england. nhs.uk/wp-content/uploads/2014/03/tech-guide-rev-allocs.pdf. Published Mar 25, 2014. Accessed Jun 12, 2015.

13. Kontopantelis, E., Buchan, I., Reeves, D., Checkland, K. \& Doran, T. Relationship between quality of care and choice of clinical computing system: retrospective analysis of family practice performance under the UK's quality and outcomes framework. BMJ Open. 2013; $2 ; 3(8)$.

14. Roland M. Linking physicians' pay to the quality of care-a major experiment in the United kingdom. N Engl J Med. 2004;351(14): 1448-1454.

15. Rhys G, Beerstecher HJ, Morgan CL. Primary care capitation payments in the UK. An observational study. BMC Health Serv Res. 2010;10:156.

16. Health and Social Care Information Centre. Indicator Portal. http:// www.hscic.gov.uk/indicatorportal. Accessed Jun 12, 2015. 
17. McLennan D, Barnes H, Noble M, Davies J, Garratt E, Dibben C. The English Indices of Deprivation: Technical Report. Department for Communities and Local Government. https://www. gov.uk/government/uploads/system/uploads/attachment_data/ file/6320/1870718.pdf. Published Mar 2011. Accessed Jun 12, 2015.

18. Office of National Statistics. Atlas of the Indices of Deprivation 2010 for England. http://neighbourhood.statistics.gov.uk/ HTMLDocs/AtlasOfDeprivation2010/index.html. Published 2011. Accessed Jun 12, 2015.

19. Aung E, Donald M, Coll J, Dower J, M Williams G, Doi SA. The impact of concordant and discordant comorbidities on patientassessed quality of diabetes care. Health Expect. 2013.

20. Pentakota SR, Rajan M, Fincke BG, et al. Does diabetes care differ by type of chronic comorbidity?: An evaluation of the Piette and Kerr framework. Diabetes Care. 2012;35(6):1285-1292.

21. Woodard LD, Landrum CR, Urech TH, Wang D, Virani SS, Petersen LA. Impact of clinical complexity on the quality of diabetes care. Am J Manag Care. 2012;18(9):508-514.

22. British Medical Association. Quality and Outcomes Framework for 2012/13. https://www.myhealth.london.nhs.uk/sites/default/files/ u1217/gpqofguidance20122013.pdf. Published Mar 2012. Accessed Jun 12, 2015.

23. Doran $\mathrm{T}$, Kontopantelis $\mathrm{E}$, Valderas JM, et al. Effect of financial incentives on incentivised and non-incentivised clinical activities: longitudinal analysis of data from the UK Quality and Outcomes Framework. BMJ. 2011;342:d3590.

24. Kontopantelis E, Springate D, Reeves D, Ashcroft DM, Valderas JM, Doran T. Withdrawing performance indicators: retrospective analysis of general practice performance under UK Quality and Outcomes Framework. BMJ. 2014;348:g330.
25. Kontopantelis E, Doran T, Gravelle H, Goudie R, Siciliani L, Sutton $M$. Family doctor responses to changes in incentives for influenza immunization under the U.K. Quality and Outcomes Framework pay-for-performance scheme. Health Serv Res. 2012;47(3 Pt 1): 1117-1136.

26. Ashworth M, Schofield P, Seed P, Durbaba S, Kordowicz M, Jones R. Identifying poorly performing general practices in England: a longitudinal study using data from the quality and outcomes framework. J Health Serv Res Policy. 2011;16(1):21-27.

27. O'Hagan JW. Tests for the severity of multicollinearity in regression analysis. Review of Economics and Statistics. 1975; 57(3):368-370.

28. de Bruin SR, van Oostrom SH, Drewes HW, de Jong-van Til JT, Baan CA, Struijs JN. Quality of diabetes care in Dutch care groups: no differences between diabetes patients with and without co-morbidity. Int J Integr Care. 2013;13:e057.

29. Heaney DC, MacDonald BK, Everitt A, et al. Socioeconomic variation in incidence of epilepsy: prospective community based study in south east England. BMJ. 2002;325(7371):1013-1016.

30. Fone D, Dunstan F, Lloyd K, Williams G, Watkins J, Palmer S. Does social cohesion modify the association between area income deprivation and mental health? A multilevel analysis. Int J Epidemiol. 2007;36(2):338-345.

31. Bae S, Rosenthal MB. Patients with multiple chronic conditions do not receive lower quality of preventive care. J Gen Intern Med. 2008;23(12):1933-1939.

32. Salisbury C, Johnson L, Purdy S, Valderas JM, Montgomery AA. Epidemiology and impact of multimorbidity in primary care: a retrospective cohort study. Br J Gen Pract. 2011;61(582):e12-e21. 